\title{
EHMTI-0021. The possible effect of telmisartan on the blood-brain barrier transport of verapamil
}

\author{
PL Saaby ${ }^{1 *}$, P Tfelt-Hansen ${ }^{2}$ \\ From 4th European Headache and Migraine Trust International Congress: EHMTIC 2014 \\ Copenhagen, Denmark. 18-21 September 2014
}

\section{Introduction}

The high doses of verapamil (480 to $960 \mathrm{mg}$ per day) needed in cluster headache prevention are most likely due to a need for the drug to exert an effect in the CNS. Verapamil is cell permeable due to its lipophilic nature, but is also, at the same time, a substrate for the BBB efflux pump P-glycoprotein (P-gp). If the efflux of verapamil could be selectively inhibited the blood concentration of verapamil needed for an CNS effect could probably be decreased.

In an in vitro study using a P388/dx cell line, "telmisar$\tan$ was identified as one of the most potent inhibitors of P-gp currently known" [Biopharm. Drug Disp. 2010; 31: 150-161.]. We therefore investigated whether telmisartan could modulate the transport of verapamil in an in vitro model of the BBB.

\section{Methods and results}

In bi-directional transport experiments $(\mathrm{n}=6)$, telmisartan $(2.4 \mu \mathrm{M})$ increased both uptake and permeability of verapamil in MDCK-II MDR1 cells cultured on permeable supports. Telmisartan also reduced the ratio between brain to blood and blood to brain transport; indicating a telmisartan-mediated modulation of verapamil efflux. Telmisartan did not affect efflux transport of digoxin.

\section{Discussion}

The main result of this in vitro of the transport across the $\mathrm{BBB}$ was the indication of a telmisartan-mediated inhibition of verapamil efflux transport. The lack of effect of telmisartan on efflux transport of digoxin might indicate that the observed effects on verapamil efflux are not related to inhibition of P-gp or that telmisartan does not block the digoxin-binding site at P-gp.

${ }^{1}$ Faculty of Health and Medical Sciences University of Copenhagen, Bioneer: FARMA, Copenhagen, Denmark

Full list of author information is available at the end of the article
No conflict of interest.

\section{Authors' details}

${ }^{1}$ Faculty of Health and Medical Sciences University of Copenhagen, Bioneer: FARMA, Copenhagen, Denmark. ${ }^{2}$ Glostrup Hospital University of Copenhagen, Danish Headache Center, Glostrup, Denmark.

Published: 18 September 2014

doi:10.1186/1129-2377-15-S1-F28

Cite this article as: Saaby and Tfelt-Hansen: EHMTI-0021. The possible effect of telmisartan on the blood-brain barrier transport of verapamil. The Journal of Headache and Pain 2014 15(Suppl 1):F28.

\section{SpringerOpen ${ }^{\odot}$}

C 2014 Saaby and Tfelt-Hansen; licensee Springer. This is an Open Access article distributed under the terms of the Creative Commons Attribution License (http://creativecommons.org/licenses/by/2.0), which permits unrestricted use, distribution, and reproduction in any medium, provided the original work is properly cited.
Submit your manuscript to a SpringerOpen ${ }^{\circ}$ journal and benefit from:

- Convenient online submission

- Rigorous peer review

- Immediate publication on acceptance

- Open access: articles freely available online

- High visibility within the field

Retaining the copyright to your article

Submit your next manuscript at $>$ springeropen.com 